\title{
Professor Georgy Speransky
}

This article is dedicated to a great Soviet paediatrician Georgy Nestorovich Speransky, who was the first director of the Institute of Paediatrics of Academy of Medical Sciences of USSR. The present-day Institute of Paediatrics is one of the few paediatric institutions included in the structure of the Scientific Center of Children's Health of Russian Academy of Medical Sciences, and in 2010 was named after G. N. Speransky. The Center collaborates with Pauls Stradiņš Museum of History of Medicine in Rīga and the Institute of History of Medicine of Rīga Stradinš University. This article is the result of cooperation between these institutions. We express our sincere gratitude to Maija Pozemkovska, the assistant Professor of the Institute of History of Medicine of Rīga Stradinšs University personally for her help and collaboration.

Sources of information for this article are the following. First, these are personal records of Georgy Speransky from the archive of the Russian Academy of Medical Sciences in Moscow. Second, the findings from the discussions with Speransky's grandson, a medical doctor, Professor Alexey Ovchinnikov, and his book about the life of his famous grandfather. Third, the numerous documents, photos and some personal belongings of Georgy Speransky, which are carefully stored by Pauls Stradiņš Museum of History of Medicine in Rīga. This article reveals some known and less known pages from Georgy Speransky's biography.

According to his personal records, Georgy Speransky was born in Moscow on 20 February (7 February by the Old Calendar), 1873 in a family of a military doctor. In 1898 he graduated the Department of Medicine of the Imperial Moscow University and got an unpaid position of a professor's assistant at the children's clinic of the same University. ${ }^{1}$ The head of

1 The Archive of Russian Academy of Medical Sciences. Fund 1, inventory 8, case 236. 
the clinic was Nil Fedorovich Filatov who is considered to be the founder of Russian paediatrics. Speransky had friendly relationship with Filatov and his family. In his childhood Speransky had studied in the gymnasium with Filatov's two sons Nikolai and Vsevolod. Both of them were Georgy's friends. In 1898 Georgy Speransky married Filatov's niece Elizaveta, and they lived together for 60 years. ${ }^{2}$

As a paediatrician, Speransky had a private practice and worked in the Aleksandro-Mariinsky Institute for noble maidens. He spoke a few foreign languages including French, German and English. In 1904-1907 he went on a scientific business trip to Germany, France, Austria, Hungary and England where he gained some remarkable experience from his foreign paediatrician colleagues. ${ }^{3}$

Since the beginning of his professional activity, Georgy Speransky was thinking about preventive paediatrics. He suggested that every paediatrician should study a healthy child from birth, but must also treat children. When Speransky presented the idea of studying healthy children for the first time, many of his colleagues did not understand why healthy babies should be studied, when diseases were taking away the lives of thousands of infants. Speransky's explanation became simple. He realised that without studying the physiology of a child, especially of a newborn, disease could never be overcome. ${ }^{4}$

In his autobiography, Speransky modestly reported that in 1906 he became the first Russian paediatrician who had stepped over the threshold of the Maternity hospital and began to observe the newborn. Before that, only obstetricians had taken care of newborns in Russian Maternity hospitals. The opening of a position of a paediatrician in the Maternity hospital had improved the situation with a high level of fatality of newborns. In 1907, in Moscow he opened the first medical consultation for mothers with infants, in 1910 the first hospital for infants with a clinic for infant

2 Chumaevskaya O. A. Georgy Nestorovich Speransky. - Moscow: Medicine, 1973. - P. 80.

3 The Archive of Russian Academy of Medical Sciences. Fund 1, inventory 8, case 236.

4 Balander A. I. The page from the History of Maternity and Infant Care // The Questions of Social Hygiene, Physiology, and Pathology of Children Ages. Moscow: Publisher of People's Commissariat for Public Health, 1929. - Pp. 21-29. 
outpatients and in 1912 a small medical centre "House for Infants". 5 Later, in Soviet Russia, upon an initiative of Speransky the special clinic for the rehabilitation of premature babies was opened. He studied problems of infant balanced feeding, particularly the methods of treatment of newborns and premature babies. This work let him and his colleagues to decrease morbidity and mortality rate of newborns and premature babies. So, we can call Georgy Speransky one of the founders of Russian neonatology.

The February Revolution of 1917 did not meet Speransky's expectations to improve the paediatrics work and decrease the high child mortality rate in the country. It was an extremely difficult period for everyone: no jobs, no food and the Red Terror of Soviet Russia. The first years after the October Revolution of 1917 were exceptionally dramatic and even tragic for Dr. Speransky and his family. In the autumn of 1918, they left the cold and hungry Moscow, moving to the south of Russia - to the city of Odessa where Elizaveta's brother Vladimir Filatov, a famous Russian ophthalmologist, was living. Shortly after that, the Bolsheviks shot Speransky's 16 years old son Nikolai, explaining that he was killed by mistake. Then his beautiful 19 years old daughter Ekaterina disappeared. In search for food she joined a crew of fishermen and left for Constantinople, Turkey, where she lost all the documents and money. To her luck, a British navy officer secretly took Ekaterina to Great Britain where they got married. Only three years later she was able to write a letter to her family telling them that she was alive. ${ }^{6}$

In 1919, Dr. Speransky found a job at the Maternity and Child Welfare Service in a small city named Maykop. The next year he moved to the city of Krasnodar, where he took the vacant position of a Professor in the Department of Childhood Diseases at the Krasnodar University Medical School.

In October 1921, Speransky was called back to Moscow to work at the Maternity and Child Welfare Service by Vera Lebedeva who had been

5 The Archive of Russian Academy of Medical Sciences. Fund 1, inventory 8, case 236.

${ }^{6}$ Ovchinnikov A. The Main Children Doctor. Is dedicated to the memory of G. N. Speransky. - Moscow: Publisher of The Union of Pediatricians of Russia, 2009. - P. 280. 
the Head of this Maternity and Child Welfare Service. She had known Speransky before as a member of special medical committee for first soviet reforms of the Russian old system of Maternity and Child Care. Meantime Speransky became the head of a clinic for critically ill children in the State House of Baby Care. In 1922, Speransky and Vera Lebedeva initiated the reorganisation of the State House of Baby Care into the State Research Institute of Maternity and Infancy. Professor Speransky became the first director of this Institute. He appeared as one of the most important organisers of the original Soviet paediatric scientific trend. He showed new approaches to study the pathogenesis of childhood diseases of infants. He and his colleagues studied the clinical symptoms, diagnostics and treatment of gastrointestinal diseases, respiratory pathology, acute and chronic infections and metabolic disorders. ${ }^{7}$

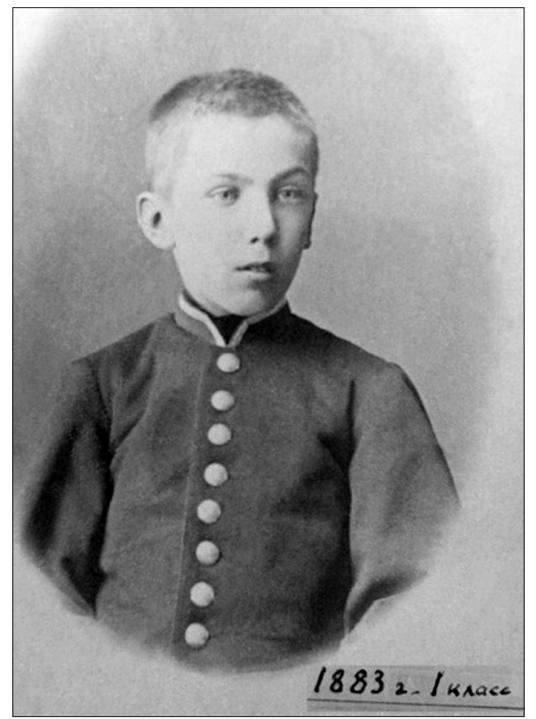

Ten-year-old Georgy Speransky is a first grade student, 1883

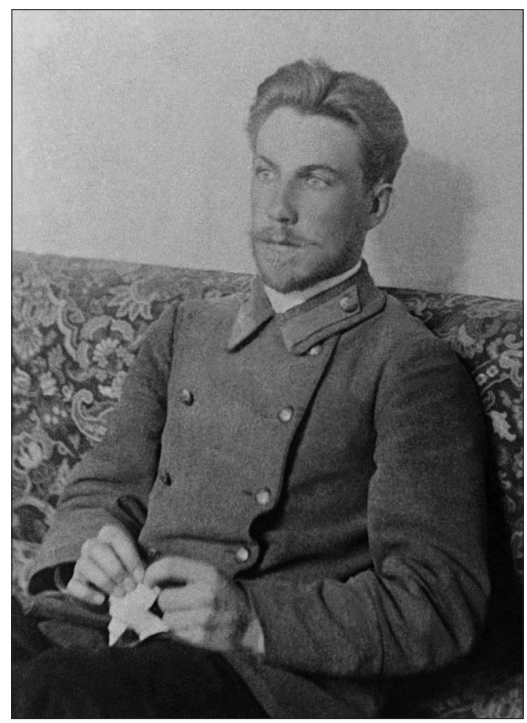

Georgy Speransky is a student of Medical School of Moscow University

7 Speransky G. N. State Research Institute of Maternity and Infancy // Proceedings of III congress of Maternity and Infancy Care. Moscow, 1925. Moscow: Publisher of People's Commissariat for Public Health, 1926. Pp. 154-160. 


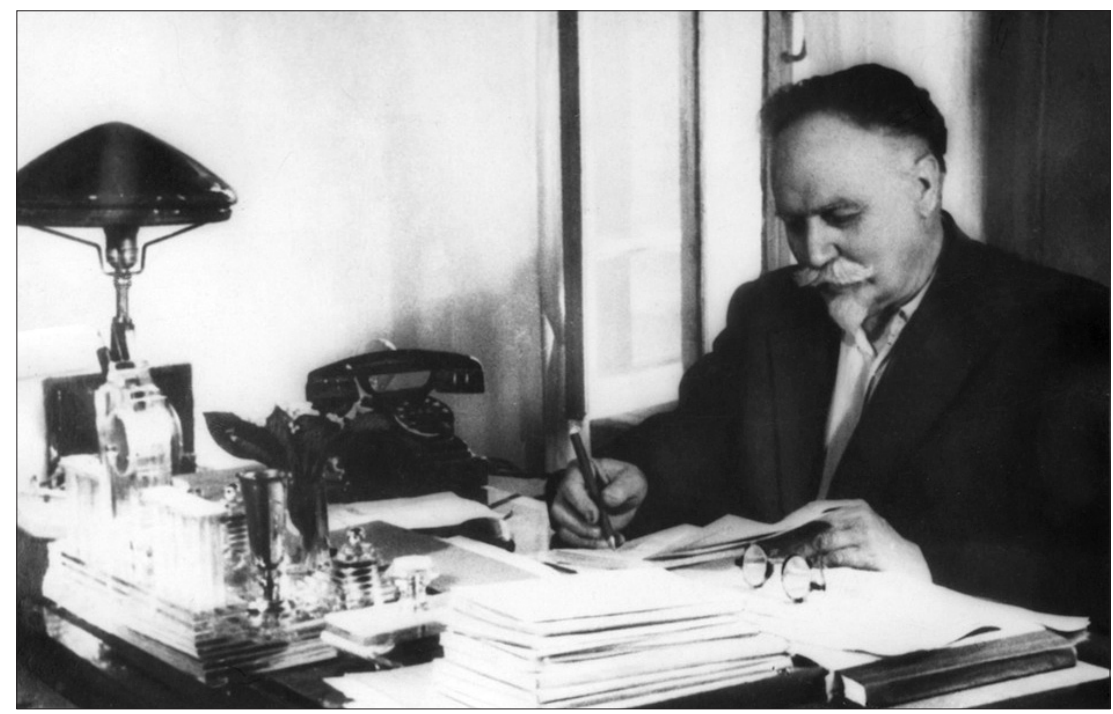

Professor G. Speransky is the director of the State Research Institute of Maternity and Infancy (1930s)

In the late 1920s, Professor Speransky paid due attention to high prevalence of infant "summer diarrhea" with follow-up hypotrophy and distrophy. In 1928, he represented classification of infant digestive disorders. He was making the plan of measures of fighting with disorder, including the study of etiology and treatment (diet therapy, very small doses of insulin, hemotransfusions, etc.). In the 1930s, Speransky concentrated on another topical paediatric problem because infant pneumonia was giving high level of mortality. He tried to prove the connection between a severity of the illness and reactivity of infant organism. Speransky offered the classification of pneumonia according to the age of a child, which helped paediatricians to diagnose and treat children. Also he was studying the features of infant sepsis. Speransky's clinic was the first in USSR where peadiatricians started to use sulfanilamides as antibacterial medications. Speransky who had a lot of students and followers created the original soviet scientific paediatric school.

In 1932, Professor Speransky left the director's post of the Research Institute of Maternity and Infancy, still keeping the position of a professor and the head of one of the paediatric clinics in the Institute. Then he organised the first medical department of childhood diseases at the Central 
Institute of Continuing Education for Medical Doctors in Russia. He continued to focus his research on physiology and pathophysiology of infants and their features. ${ }^{8}$

By the 1930s, Professor Speransky was a famous, respected and honored paediatrician of the Soviet Union. He was called the primary paediatrician of the Kremlin, treating the children of Joseph Stalin and of other high-ranking members of the Communist party. These circumstances allowed Speransky to come to defend his older brother, an academician and famous philologist, Michael Speransky who was arrested in 1934. Michael Speransky was suspected of anti-Soviet activity in the so-called "Slavist's case". To help his brother, Georgy Speransky addressed a letter to Stalin. A few days later, Michael Speransky was released, yet excluded from the Academy of Sciences of USSR and dismissed from his job. ${ }^{9}$

In the early 1950s, during the Doctors' plot episode, Speransky was not afraid to protect one of the blamed medical doctors, his colleague and friend, Professor Vladimir Vinogradov.

In 1940, as the age of patients had gradually extended from infants to older children, the Research Institute of Maternity and Infancy had transformed into the Institute of Paediatrics. When World War II started in the Soviet Union, the staff of the Institute of Paediatrics was evacuated to the Urals. Speransky and his family moved to the Ural city of Molotov, present-day Perm, where Georgy worked in a railroad hospital as a paediatrician's consultant. He aided many children evacuated from front-line. He did research to create a milk surrogate for newborns. He saved lives and improved health of many children ill with dystrophy, pneumonia, digestive diseases, etc. Returning to Moscow, Speransky was awarded the Order of Lenin for his irreproachable work. In 1943, Speransky was elected as corresponding member of the Academy of Science of USSR and in 1945 he became a member of the Academy of Medical Sciences. In 1947, he received the second Order of Lenin in honor of the $25^{\text {th }}$ anniversary of the Institute of Paediatrics. ${ }^{10}$

8 The Archive of Russian Academy of Medical Sciences. Fund 1, inventory 8, case 236.

9 Ashnin F. D. \& Alpatov V. M. // Slavist's case. 1930s. - Moscow: Publisher "Heritage" (In Russian: "Nasledie"), 1994. - Pp. 88-97.

10 Chumaevskaya O. A. Georgy Nestorovich Speransky. - Moscow: Medicine. 1973. - P. 80. 


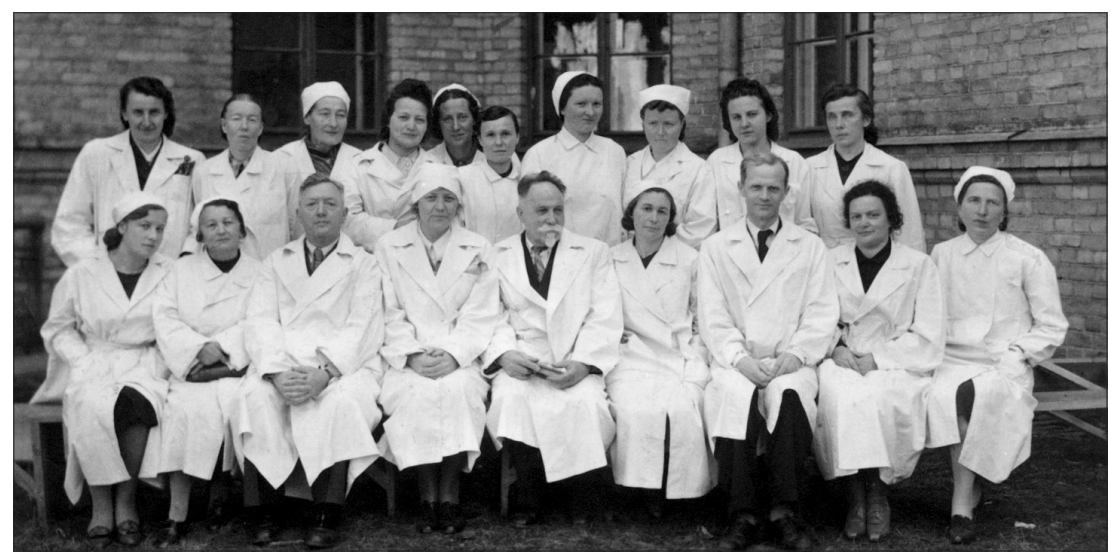

Professor G. Speransky with his colleagues at Republican Clinical Children's Hospital, Rīga, 1946

In 1945, the Institute of Paediatrics received the status belonging to the highest scientific and medical organisation, to the Academy of Medical Sciences of USSR. In 1948, Speransky was again appointed director of the Institute of Paediatrics. There he did a tremendous amount of clinical, research and administrative work. He was an expert in any field of paediatrics with special attention to preventive paediatrics and neonatology.

A special part of Speransky's life is connected with postwar Latvia where he was in 1946. Since 1948, when the Academy of Medical Sciences of USSR opened a health resort for soviet scientists on Riga seaside between Lielupe and Bulduri, Speransky and his family were visiting Latvia almost annually. ${ }^{11}$

In addition to the health-improvement and relaxation, G. Speransky had made friends among his Rīga colleagues, both business and private contacts. For that reason, the funds of P. Stradinš Museum of History of Medicine are keeping some very interesting correspondence between Georgy Speransky and Tamara Vishnevetskaya, who was working in the Republican Children's Hospital at first as a peadiatrician, then as the head of a clinical department. ${ }^{12}$

11 Ovchinnikov A. The Main Children Doctor. Is dedicated to the memory of G. N. Speransky. - Moscow: Publisher of The Union of Pediatricians of Russia, 2009. - P. 280.

12 Vīksna A. Latvijas medicīnas jubilejas 1994. - Rīga, 1993. - 13. lpp. 


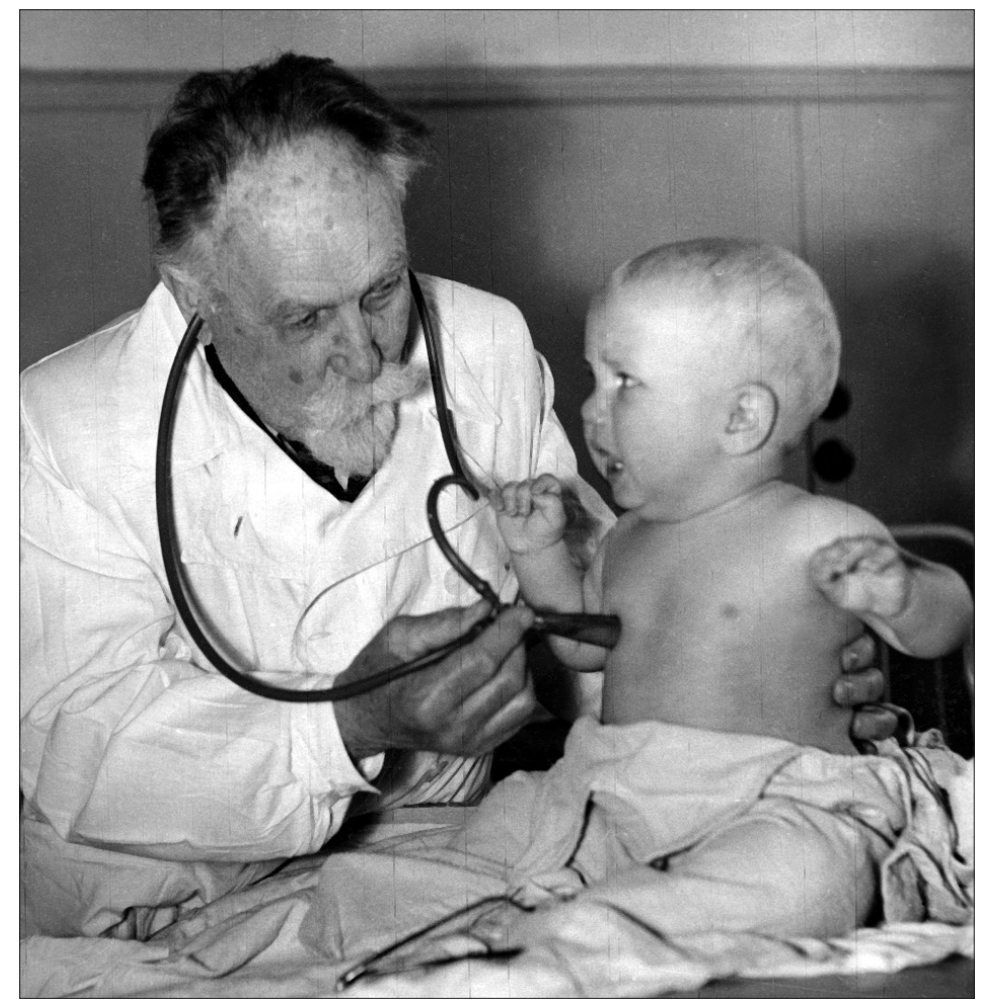

Professor G. Speransky checks-up one of his small patients (1950s)

Exchanging their clinical experience, Speransky and Vishnevetskaya discussed different paediatric problems in their letters. For instance, Speransky had asked to prepare some specific autovaccine from nasopharyngeal microflora for his 10 -year-old patient with asthmatic syndrome provoked by some infection. Another letter was about a new drug furazolidone, which was approbated at the clinic of Dr. Vishnevetskaya, for the treatment of small patients with diarrhea. Speransky had asked to send the furazolidone to treat children with dysentery, using this antibacterial drug. One of Speransky's letters (25 November 1951) acknowledges the presentation Vishnevetskaya's report at the VII Congress of Soviet paediatricians in Leningrad. A few letters from various years were about Vishnevetskaya's publications, in particular: a collection of scientific articles from the First Conference of Rìga Clinical Children's Hospital; the textbook of treatment 
methods for children's digestive diseases; the book "From the Experience of Children's Doctors", dedicated to the $60^{\text {th }}$ anniversary of Riga Clinical Children's Hospital. ${ }^{13}$

We have also found an unusual letter written to G. Speransky in 1968 by one of Rīga residents, Austra Lācis. She was remembering 1915, the times of the First World War, when she, a 24-year-old lady, and her family were evacuated from Rīga to Moscow. A few months later she gave birth to her son, who survived very serious diarrhea. Only Dr. Speransky was able to save the health and life of her baby. After the war she came back to Rīga, but all her life she had felt sincere appreciation to this doctor. In April 1968, reading the newspaper Rīga's Balss, she had come across an article "A man cannot be old" about professor Speransky. A 75-year old, Austra Lācis and her son, who was already 52 years old at the time, with the pleasure had discovered that Dr. Speransky was alive, and wrote to him this letter. ${ }^{14}$

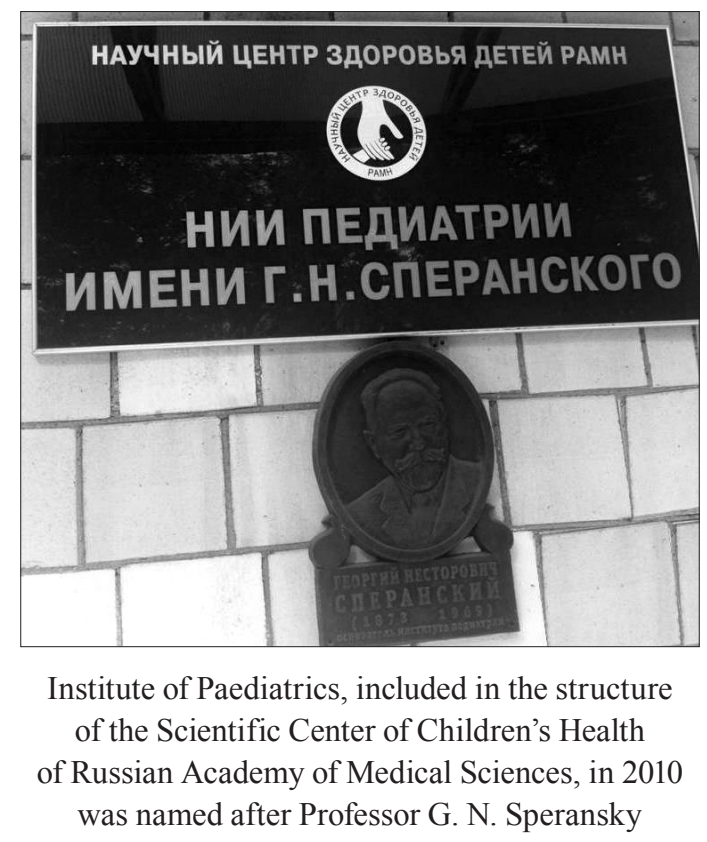

13 Funds of manuscripts and documents of the Archive of Riga Pauls Stradins Museum of the history of medicine, N 1/52, R-6234.

14 Ibid. 
In 1951, Speransky directed a petition to the President of the Academy of Medical Sciences of USSR about his health problems and his necessity to leave the post of the director. From then on, he had worked as a scientific advisor at the Institute of Paediatrics. In 1957, Speransky was awarded the title of Hero of Socialist Labor.

In 1958, the beloved wife of Speransky, Elizaveta passed away. It was a very hard loss for him after which he could not work, and retired. Speransky passed away on 14 January 1969. It was a suicide, but the secret was divulged only three years ago. ${ }^{15}$

In 1970, the Soviet government appreciated Speransky's merits of decreasing infant mortality ten times. In a year after his death, Speransky was awarded posthumously the Lenin Prize. Speransky had lived a long, interesting, bright, yet very difficult life and left numerous students and followers not only in Russia, but all around the world.

From the book in memory of Speransky, his grandson Professor Alexei Ovchinnikov wrote:

"My grandfather was born and studied at a gymnasium in days of Emperor Alexander II, he studied at the Imperial Moscow University Medical School in days of Emperor Alexander III, he received a diploma of medical doctor and started to work as a children's doctor in days of Emperor Nikolai II. During the Russian Revolution of 1917, Speransky was 44 years old and an experienced paediatrician. When Vladimir Lenin died, Speransky was 51 years old. Speransky became an academician in the days of Joseph Stalin, who died on the day of Speransky's $80^{\text {th }}$ birthday. Speransky received the Gold Star Medal of the Hero of Socialist Labour from Nikita Khrushchev. When Speransky was 93 years old, Leonid Brezhnev became General Secretary of the Communist Party of the Soviet Union. Speransky died at the age of 96. He survived three Russian tsars, four communist leaders, four wars and two revolutions, the 1930s period of political repression and persecution, and the Thaw period from the mid 1950s to the early 1960s. During his long life he cured an innumerable amount of children of different ages and different social groups." 16

15 Ovchinnikov A. The Main Children Doctor. Is dedicated to the memory of G. N. Speransky. - Moscow: The Union of Pediatricians of Russia, 2009. - P. 280. 16 Ibid. 


\section{Profesors Georgijs Speranskis \\ (1873-1969)}

\section{Kopsavilkums}

Raksts veltīts izcilajam krievu pediatram profesoram Georgijam Speranskim, kura ieguldījums Krievijas un padomju pediatrijā ir nenovērtējams. G. Speranskis ir pazīstams kā viens no Krievijas neonatoloǵijas pamatlicējiem, viņš bija PSRS pirmā Valsts Mātes un bērna aizsardzības zinātniski pētnieciskā institūta organizētājs, direktors un zinātniskais vadītājs. Viņš radīja oriǵinālu padomju zinātnisko pediatrijas skolu. G. Speranskis Ārstu pilnveidošanās centrālajā institūtā organizēja Krievijā pirmo Bērnu slimību katedru, viņš ar kolēgiem lasīja mācību kursu par agrīnā vecuma bērnu fizioloǵiju un patoloǵijām. Profesors bija viens no iniciatoriem radīt valsts bezmaksas sitēmu mātes un bērna aizsardzībai. Z̄ìdaiņu mirstību valstī izdevās samazināt desmitiem reižu tieši vina nerimstošās darbības dēḷ.

Rakstā atspoguļots ne tikai G. Speranska pamatieguldījums Krievijas pediatrijā, bet atainotas arī mazāk zināmas, dramatiskas un pat traǵiskas viņa dzīves gājuma lappuses, ieskaitot boḷševiku īstenoto vecākā dēla nošaušanu Odesā, kur viņš 1918. gadā, glābjoties no bada, ar ǵimeni ieradās pie dzīvesbiedres brāḷa, izcilā oftalmologa Vladimira Filatova. Tur bez vēsts pazuda arī viņa vecākā meita, kuru likteņgaitas aizveda uz Angliju. G. Speranskis, būdams Kremḷa pediatrs, ārstēja Staļina un citu augsti stāvošu padomju Politbiroja darbinieku bērnus, tāpēc 1934. gadā varēja izglābt no cietuma savu vecāko brāli, ko apsūdzēja pretvalstiskā sazvērestībā.

Rakstā īpaša vieta atvēlēta G. Speranska saiknei ar Latviju. Stāstīts par viṇa kolēǵiem Rīgas klīniskajā bērnu slimnīcā. Šeit izmantota viṇa sarakste ar Rīgas pediatri T. Višnnevecku, ar kuru profesoru saistīja ilgi draudzības un profesionālās sadarbības gadi, kā arī ievietota 1968. gada aprīlī rakstīta kādas Rīgas iedzīvotājas vēstule, kurā viņa pateicas ārstam par viņas bērna glābšanu Maskavā Pirmā pasaules kara laikā, kad mazulis cieta no smagas diarejas.

Par savu izcilo ieguldījumu pediatrijā G. Speranskis saṇēma vairākus augstus valdības apbalvojumus. 1970. gadā - jau pēc nāves - viņam tika piešksirta L̨eņina prēmija. 
Profesora G. Speranska mazdēls, arī profesors, A. Ovčiņnikovs uzrakstīja grāmatu par savu izcilo vectēvu, kas nomira 96 gadu vecumā, pārdzīvojot trīs Krievijas carus un četrus komunistiskos diktatorus, četrus karus un divas revolūcijas, 30. gadu represijas un 60. gadu "atkusni", visā šajā laikā izārstējot milzīgu skaitu dažāda vecuma bērnu no visiem sociālajiem slāņiem.

Stella Sher, $P h D$

Scientific Center of children's health, Russian Academy of sciences anastel@mail.ru

Nina Drach (1943-2014)

Pauls Stradins Museum of the history of medicine 